\title{
Working
}

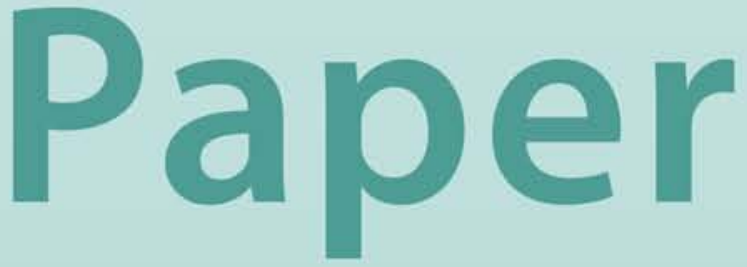




\section{Catalyzing Capital Flows: \\ Do IMF-Supported Programs Work as Commitment Devices?}

Ashoka Mody and Diego Saravia 


\title{
IMF Working Paper
}

\author{
Research Department \\ Catalyzing Private Capital Flows: \\ Do IMF-Supported Programs Work as Commitment Devices?
}

Prepared by Ashoka Mody and Diego Saravia ${ }^{1}$

May 2003

\begin{abstract}
The views expressed in this Working Paper are those of the author(s) and do not necessarily represent those of the IMF or IMF policy. Working Papers describe research in progress by the author(s) and are published to elicit comments and to further debate.
\end{abstract}

An objective of IMF-supported programs is to help countries improve their access to international capital markets. In this paper, we examine the issue whether IMF-supported programs influence the ability of developing country issuers to tap international bond markets and whether they improve spreads paid on the bonds issued. We find that IMF-supported programs do not provide a uniformly favorable signaling effect-that is, the mere existence of a program supported by the IMF does not act as a strong "seal of good housekeeping." Instead, the evidence is most consistent with a positive effect of IMF-supported programs when they are viewed as likely to lead to policy reform and when undertaken before economic fundamentals have deteriorated significantly. The size of the IMF-supported program matters, but the credibility of a joint commitment by the country and the IMF appears to be critical.

JEL Classification Numbers: F22, F33, F34

Keywords: IMF programs, signaling, capital market access

Authors' E-mail Addresses: amody@imf.org; saravia@econ.bsos.umd.edu

\footnotetext{
${ }^{1}$ We are grateful to Rich Kelly for data and guidance on Fund programs and to Roger Betancourt, Graham Bird, Michael Bordo, Jim Boughton, Fernando Broner, Patrick Conway, Barry Eichengreen, Kristin Forbes, Federico Guerrero, Alessandro Rebucci, Carmen Reinhart, John Shea, Antonio Spilimbergo, Jeromin Zettlemeyer, and seminar participants at the University of Maryland for helpful comments and discussions.
} 


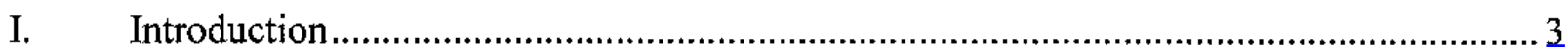

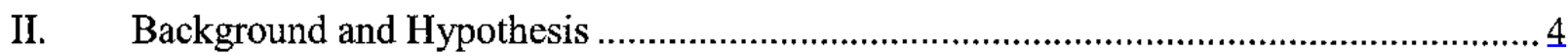

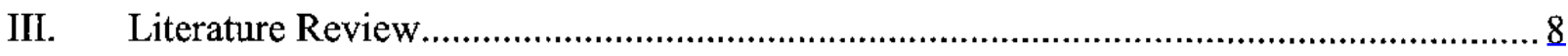

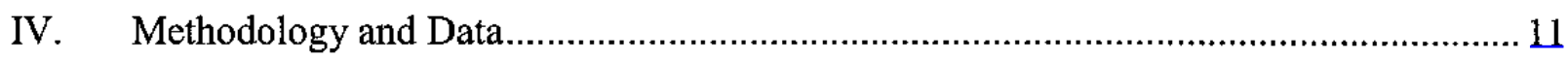

A. Framework for Analyzing Spreads............................................................... 11

B. Evaluating IMF Programs: Econometric Issues ……….....................................13

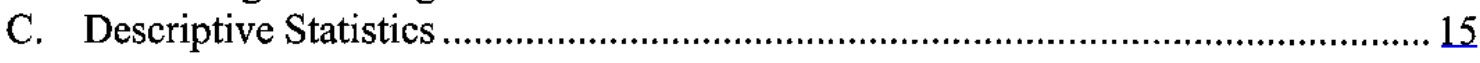

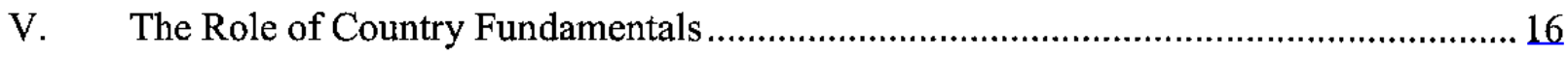

VI. Implications of Fund-Supported Program Design .................................................... 18

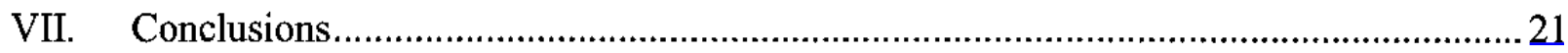

Appendixes

I. Data Sources and Construction of Variables ………..............................................29

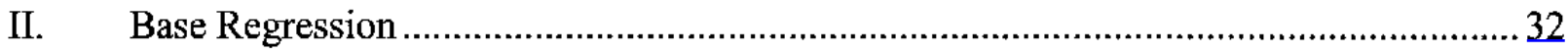

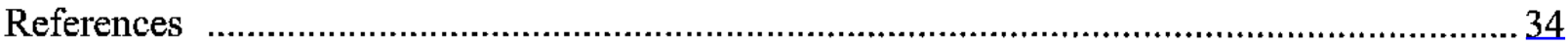

\section{Tables}

1 Frequency of IMF-Supported Programs .............................................................24

2. Bond Issuance, Terms, and Country Characteristics …………………………..........25

3. Interaction of Country Characteristics with Fund Programs .......................................26

4. Influence of Program Features on Bond Market Spreads and Issuance ………….........22

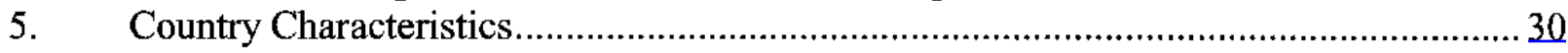

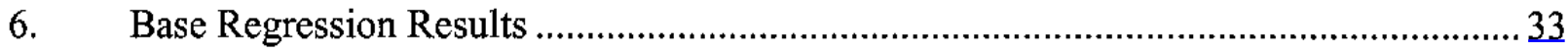

Figure

1. Econometric Implications of Timing IMF Programs ...............................................28 


\section{INTRODUCTION}

Does the International Monetary Fund (IMF or Fund) succeed in its objective of "catalyzing" capital flows to developing economies? A not inconsiderable literature concludes that the answer is "no"- that is, Fund programs do not enhance countries' access to capital markets and, indeed, a program may actually make things worse in this respect (for a recent review, see Bird and Rowlands, 2002).

Why would we expect to observe a catalytic effect? International contracts, more so than domestic contracts, are incomplete, and foreigners are, therefore, often unwilling to lend. A Fund program can potentially substitute for missing contracts and act as a commitment device that improves access to international capital. The Fund's role is, in Tirole's (2002) terminology, that of a "delegated monitor," mediating between the country and international investors.

In this paper, we explore the possibility that the delegated monitoring role works, and successful catalysis occurs, when a credible joint commitment by the country and the Fund which leads to improved prospects for honoring debt contracts. In other words, the catalytic effect - or the Fund's "seal of approval"- is not automatic and the mere presence of a Fund program does not lead to more capital flows. Rather, an IMF program is effective as a commitment device when other available information does not negate its credibility. As such, the value of the commitment implied by a Fund program, and its ability to catalyze capital flows, are likely to depend on initial country conditions, program design, and the countryFund relationship. Our contribution then is to move from a presumption of undifferentiated effects to identify country, program, and relationship characteristics that create the conditions for credible commitments and, hence, contribute to enhanced capital flows under IMF programs.

We reach four conclusions that outline the conditions under which the market values the Fund's role as a commitment device:

- $\quad$ The presence of a Fund-supported program reduces the adverse effect that a country's export volatility has on its access to international markets and cost of funds. It is as if contracting a Fund program strengthens commitment to repay when volatility is high.

- An IMF program is effective when foreign exchange reserves and debt levels make the country vulnerable but have not deteriorated to a point where their restoration to normal levels within a reasonable time frame has a low probability. Thus, the Fund catalyzes flows when, for example, solvency is not at stake.

- The size of the Fund-supported program matters, but large programs have often been successful when the money committed has not actually been used, suggesting that their precautionary deployment can be valuable. 
- $\quad$ Repeated relationships between a country and the Fund can imply commitment to solve structural problems, but diminishing returns set in as use of Fund resources is prolonged, suggesting that, beyond a certain point, the likelihood of improvement in performance begins to be called into question.

Our empirical analysis centers on the ability of Fund programs to help developing country issuers tap international bond markets and to reduce spreads paid on the bonds issued. We use an empirical model developed by Eichengreen and Mody (2001) to evaluate the determinants of international bond issuance and of spreads charged at the time of issuance. The transactional data used reduce the severity of the reverse-causality problem-that is, the possibility that observed outcomes influence the likelihood of Fund programs. This is so because the feedback from an individual bond issue to explanatory country aggregates is likely to be less serious than when the dependent variable is, itself, a country aggregate such as growth or capital flows. At the same time, by allowing a more careful consideration of timing than was possible in past studies, transactional data at higher frequency allow us to more precisely consider the rate of issuance and spreads paid in the period following the initiation of a Fund program and, hence, further reduce the problem of reverse causation.

In the next section, we provide a brief background of the Fund's objective in stimulating capital flows and its ability to act as a "delegated monitor." We then review the literature on the impact of IMF programs to identify key substantive conclusions and methodological issues. This is followed by a description of the methodology and data. The empirical results deal first with the influence of initial country conditions and then with the implications of Fund program design. The final section concludes.

\section{BACKGROUND AND HYPOTHESIS}

Enhancing its members' access to international capital markets is widely regarded as an important objective of the International Monetary Fund. Though the objective is not an explicitly stated purpose in the Fund's Articles of Agreements, the flow of international capital is essential to such stated purposes as the stability of the international monetary system, efficient trade, and productive resource use, and to providing confidence when a member country experiences difficulties with its balance of payments. ${ }^{2}$ The Fund's interest in private international capital flows has, moreover, increased over the last decade. Reflecting this evolution, the Fund's Managing Director affirmed in a recent speech:

${ }^{2}$ Article I of the International Monetary Fund's Articles of Agreement lists a number of objectives ("purposes") for the Fund. These include international monetary cooperation, facilitation of international trade to enable productive use of resources, exchange rate stability, establishment of a multilateral system of payments, and giving confidence to its members by making available the general resources of the Fund to permit "correction of maladjustments" in their balances of payments without a high cost to the domestic or international economy. 
Because private flows are an indispensable source of financing for development, another crucial function of the IMF's new Capital Markets Department will be to strengthen our ability to help countries gain access to international capital markets (Köhler, 2001, para. 13).

The Fund's monitoring function is critical to the catalytic role it plays. ${ }^{3}$ Fund resources do help and Fund financing can signal confidence in the course the country is charting. But it is the signal that counts and hence the Fund's knowledge of, and confidence in, the country's policies is necessary to induce private capital flows. The Fund's website describes its role in these very terms:

In most cases, the IMF, when it lends, provides only a small portion of a country's external financing requirements. But because the approval of IMF lending signals that a country's economic policies are on the right track, it reassures investors and the official community and helps generate additional financing from these sources. Thus, IMF financing can act as an important lever, or catalyst, for attracting other funds. The IMF's ability to perform this catalytic role is based on the confidence that other lenders have in its operations and especially in the credibility of the policy conditionality attached to its lending. ${ }^{4}$

Tirole (2002, p. 99) refers to such a role as "delegated monitoring." The IMF, Tirole argues, acts to "substitute for the missing contracts between the Sovereign and individual foreign investors and to thereby help the host country to fully benefit from its capital account liberalization." Tirole notes that missing contracts are not just a problem when foreigners lend to the sovereign. The problem is serious even when the lending is to private domestic

${ }^{3}$ Each member country is required by Article IV of the Articles of Agreement to, among other things, foster orderly growth, price stability, and orderly monetary and financial conditions. Article IV authorizes the Fund to oversee compliance of member countries with these obligations. The Fund is asked-and has agreed in the past-to monitor and certify a country's policy program without any commitment of resources. A distinction may be made, in this context, between the role of the Fund's staff and that of its Board. A positive staff report can signal to investors a professional judgment that the country has a credible adjustment program. The Board's approval sends a signal that the international community is prepared to support the country's program. At least in theory, these two signals can be distinct and separable. The Fund's Board "expressed some degree of reservation" about unbundling policy certification (or "enhanced surveillance") from the use of its resources (Boughton, 2001, p. 413).

${ }^{4}$ http://www imforg/external/publs/ft/exrp/what.htm. 
borrowers. The ability of private borrowers to repay is a function of a variety of government actions that are unpredictable and can de facto expropriate foreign lenders.

In this paper, we examine the implications of Fund programs for capital market access. A program combines resources and surveillance, with different programs offering different combinations of these functions. Programs are typically contracted in periods of external economic imbalances, though the extent of the imbalance varies and countries can, and do, enter programs for "precautionary" reasons. For a Fund program to catalyze new private capital flows, it must credibly convey a significant likelihood of success-an improvement in the program country's external payments position and growth prospects. Success of a program, in turn, depends on several factors. In particular, country and global market conditions influence the outcome. To deal with this heterogeneity, Fund programs differ in design (e.g., size of resources, duration, and the nature and extent of program conditionality). In addition, program outcomes depend on country-Fund relationships, reflected, for example, in the frequency of programs.

With respect to country conditions, an important consideration in the sovereign debt literature has been the volatility that a country is exposed to. In an early contribution, Eaton and Gersovitz (1981) argued that when countries are exposed to a high degree of volatility, they are more likely to repay their external debt since failure to do so would close them off from international borrowing and thus prevent them from dampening the future effects of continued volatility. But countries with high volatility may also find it more difficult to repay debt-or may be able to use the fact of the volatility to claim inability to repay debt. In assessing these countervailing forces, Catao and Sutton (2002) find that macro volatility is a strong predictor of sovereign debt defaults. Thus, under volatile conditions, a commitment device should help. A Fund program is a joint commitment. From the country, it is a commitment to good policies, and from the Fund, to provide resources that serve as a substitute for a country's reserves.

Commitment through the Fund, however, is likely to be effective when countries are vulnerable but have not yet crossed thresholds that imply inability to service external debts even with Fund assistance. When vulnerability is high, the role of a "delegated monitor" may be especially valuable if a country's commitment to international contracts is more suspect than in "tranquil" or more normal periods. Also, in periods of vulnerability, information about the country may be fuzzy. However, when a country is past the point of vulnerabilitywhen reserves and external debt levels have reached levels that imply low probability of reversing into a more normal state - the country's ability and incentives toward achieving policy objectives are likely to be suspect and the Fund's leverage in this respect is likely to be limited. ${ }^{5}$ Thus, for example, a Fund program is unlikely to catalyze new capital when

\footnotetext{
${ }^{5}$ Powell (2002) suggests that a country's response to a Fund program is likely to weaken as its economic situation deteriorates. Supporting that notion, Ivanova, Mayer, Mourmouras, and Anayiotos (2001) find that larger government fiscal deficits, which they believe reflect internal political competition, are associated with more frequent program failure.
} 
solvency is at stake. Even if a country does not "gamble for resurrection," as some have argued (e.g., Powell, 2002), new shocks will continue to prevent recovery. In such a situation, the Fund as a delegated monitor will add limited value.

In recent theoretical contributions, Morris and Shin (2003) and Corsetti, Giumarães, and Roubini (2003) reach a similar conclusion. They show that IMF lending is most effective in catalyzing capital flows when a country is an "intermediate" zone between bad and good fundamentals. In this intermediate, or vulnerable zone, an IMF program elicits an adjustment effort (IMF program and country effort are strategic complements). An implication of this analysis is that not all IMF lending is the source of moral hazard. To the contrary, lending generates a positive country response in the vulnerable region; moral hazard kicks in when fundamentals are irretrievably bad.

These considerations are consistent with the Fund's own preferred approach to early intervention. For example, in discussing policy toward access to Fund resources, the Fund's Treasurer's Department notes:

Over the years, it has come to be recognized that the efficacy of the mixture of adjustment policies and financing depends largely on the early adoption of corrective policy measures. Early resort to an adjustment program supported by IMF resources can help to avoid more drastic policy actions that may otherwise be required, thereby limiting the impact of the adjustment on other members. (IMF 2001a, p. 29)

A 1979 decision by the Fund's Executive Board had an almost identical wording: "Members should be encouraged to adopt measures...at an early stage of their balance of payments difficulties or as a precaution against the emergence of such difficulties."

The Fund can signal strong commitment by making available a large amount of resources. All else being equal, we would, therefore, expect programs with larger resources (in relation to country debt obligations) to be associated with better capital market access. However, the joint commitment is even stronger when the country does not actually use those resources. In that situation, a country subjects itself to the discipline implied by a Fund program without drawing on the available resources. The delegated monitoring function should be particularly valuable in such programs that are "precautionary" in nature.

Finally, the Fund can signal commitment by deeper engagement in a country. One measure of deeper engagement is the length of time over which a country contracts a Fund program. Where problems are of a structural nature, markets are likely to value the continued presence

${ }^{6}$ Decision No. 6056-(79/38), March 2, 1979, in IMF (2001b), pp. 167-168. 
of the Fund. However, excessive repetition of Fund programs ("prolonged use") is likely to reduce the perception of the country's commitment and the Fund's ability to resolve matters.'

\section{LITERATURE REVIEW}

In this review, we cover three aspects of the literature. First, we briefly describe the main body of the literature on IMF programs, which focuses on their macro implications. Second, we discuss the smaller set of writings on the Fund's ability to catalyze private capital flows. And, finally, we discuss two methodological issues (the need to move away from considering programs as homogeneous and correcting for sample selection bias arising from unobserved differences between program participants and nonparticipants).

On the implications of IMF programs for macro country performance, the results display considerable consistency despite different methodologies and coverage of different time periods. Two early studies (Edwards, 1989, and Khan, 1990) reached three conclusions that have stood the test of time. First, Fund programs help improve the external payments position, this improvement takes effect relatively quickly, that is, within a year, and is sustained beyond the program. Second, the impact on inflation is statistically insignificant. Third, growth actually suffers during the period of an IMF program but recovers once the program ends, though possibly not to the level prior to the initiation of the program. ${ }^{8}$ The problem of the appropriate counterfactual against which to compare IMF programs has plagued all studies. ${ }^{9}$ However, continued econometric refinement confirms these findings (Mussa and Savastano 1999).

${ }^{7}$ In light of results obtained by Stone (2002), loss of credibility when there is a high incidence of program repetition may also reflect that such repetition reflects, in part, political affinity with the United States, which serves to reduce the incentive to undertake demanding reform measures.

${ }^{8}$ Much of the recent debate has centered on the growth effects. Przeworski and Vreeland (2000) find the most significant adverse effect on growth. Hutchison (2001) finds a small negative growth effect while Barro and Lee (2001) find that a Fund program has no impact on growth. At the other extreme, Dicks-Mireaux, Mecagni, and Schadler (2000), who focus only on countries that undertake structural adjustment programs and hence are in the lowincome category, find a significant positive growth effect of IMF programs.

${ }^{9}$ The generalized evaluation estimator suggested by Goldstein and Monteil (1986) and employed by such influential papers as Khan (1990) and Conway (1994) has been the preferred approach to dealing with the problem of the counterfactual. For recent applications, see Dicks-Mireaux, Mecagni, and Schadler (2000) and Hutchison (2001). This estimator allows for the possibility of "mean-reversion," that is, of a return towards normalcy from distress even in the absence of a Fund program, possibly on account of an endogenous policy response. 
That the maximum effectiveness is achieved with respect to the external payments situation is not surprising. The Fund's principal objective and its analytical approach both lead to that focus. Fisher (1997) notes: "Fund programs are designed to restore balance-of-payments viability, and more generally to restore macroeconomic stability-seen as a necessary condition for economic growth." ${ }^{\text {"10 }}$ Thus, though growth is an objective, especially in programs that have longer duration and greater structural content, the immediate emphasis is on the external payments position (see also Schadler and others, 1995). The ambiguity with respect to the growth effect follows, as Krueger (2000) notes, from the remedy in addressing the traditional balance-of-payments crises: devaluation of the domestic currency and tightening of monetary and fiscal policy to contain domestic demand.

On the indicator of most interest to this paper, private capital flows, strong presumptions, anecdotal evidence, and statistical analysis lead to quite different conclusions. It is often taken as axiomatic that a Fund program is necessary for the resumption of capital flows (Dhonte, 1997, and Fisher, 1997). Bird and Rowlands (2001a) say it is a "commonly held view" that the IMF helps attract private capital to a country by endorsing the country's economic reform plan. They cite, for example, a U.K. Treasury Committee report on the IMF that refers to "an all pervasive conventional wisdom" that an IMF program buys a "good housekeeping seal of approval." Marchesi and Thomas (1999) state: "Overall, there is evidence to suggest that those who accept the intervention of the Fund can more easily obtain better conditions on their loans, consistent with our thesis that program adoption plays an information role." However, with the one exception of Marchesi (2001), which is a follow-up to the Marchesi and Thomas (1999) paper, the statistical evidence to date goes the other way.

Killick, Malik, and Manuel (1992) do a before-after comparison of net capital flows and find that these flows decline after an IMF program is put in place. Much of the decline is due to an increase in repayments rather than to a decline in gross inflows. Bird and Rowlands (1997 and 2001a) are especially skeptical of the Fund's "catalytic effect." They find no empirical evidence for such an effect, consistent with their priors. IMF programs are a sign of economic distress and they are not persuaded that the country's macroeconomic performance improves following the start of a program. Similarly, in a regression to explain spreads charged on commercial bank loans, Ozler (1993) finds a positive sign on the dummy variable for an IMF program, suggesting that the program is an indicator of "repayment difficulties." 11 These studies, however, have their limitations. Ozler's results are quite sensitive to the inclusion of other explanatory variables. Once variables are added to characterize the loan and whether a country achieved sovereign status only recently, the magnitude of the coefficient falls sharply and it is no longer significant at the 5 percent level.

\footnotetext{
${ }^{10}$ This focus leads to a Fund program being "built around three identities: the central-bank balance sheet, the balance of payments constraints, and the government budget constraints."

${ }^{11}$ Hajivassiliou (1986) has the same interpretation as Ozler (1993) in his estimate of a supply function for capital where he finds that a dummy variable representing IMF programs (and also instances of debt rescheduling) is associated with reduced capital flows.
} 
The Bird and Rowlands (1997 and 2001a) and Ozler (1993) analyses also do not formally address the possibility that a drop in capital flows may trigger IMF programs, the reverse causality or selection problem.

Edwards (2000), in reexamining the catalytic effect of Fund programs, takes on board the possibility that self-selection into Fund programs may bias the results, but finds that correction for self-selection makes no difference-there is still no evidence of a catalytic effect. This is not surprising since probit estimates of program participation fare poorly in their predictive ability (Hutchinson, 2001, and Garuda, 2000), and tend, moreover, to be highly sensitive to choice of sample (see, especially Bird and Rowlands, 2001b, for an extensive discussion of the history and weaknesses of these estimates). Edwards does find, however, that program countries that have a recent history of lack of compliance with the agreed reform agenda are penalized in terms of access to capital markets. Thus, he finds evidence for an asymmetric effect: Fund programs do not necessarily help, but programs with noncompliance appear to hurt. The important point the paper makes is that all Fund programs cannot be taken to have the same effect since the nature of country and Fund involvement is likely to vary considerably across programs.

The one study that finds an indirect impact of IMF programs on capital market access is that by Marchesi (2001). She examines a country's ability to reschedule its private debt obligations and finds that the presence of a Fund program helps in this respect. She interprets her finding to imply that participation in a Fund program signals a commitment to policy reform that is a precondition to debt rescheduling and continued market access.

The bulk of the literature described above treats IMF programs as undifferentiated. Thus, a single dummy variable represents the presence or absence of a Fund program. However, differences between Fund programs have recently received some attention. An advance, in this respect, is distinguishing between types of Fund programs (for example, Stand-By Arrangement and Extended Fund Facility) as in Eichengreen and Mody (2001) and Bird and Rowlands (2002). In addition, program effectiveness is likely to vary by country conditions. Edwards (2000), as noted, finds differential effects for countries in compliance with the program. Ivanova, Mayer, Mourmouras, and Anayiotos (2001), in explaining the success or failure of Fund programs, distinguish between countries on the basis of internal political competition for resources. Stone (2002) focuses on a number of differences, important among which is a measure of the country's political affinity to the United States as a proxy for the inability of the Fund to discipline domestic policymakers in that country. Garuda (2000) also differentiates across country characteristics. ${ }^{12}$ Specifically, within the group of countries with a high propensity to enter IMF programs, an IMF program is associated with a

${ }^{12}$ He classifies countries by a "propensity" score, that is, by a measure of the likelihood that may be in a Fund program. A country's propensity is derived from a probit as the probability of $\mathrm{MF}$ program participation and is a function of such variables as growth, inflation, reserves, and current account balances of current and past periods. 
worsening of income distribution. In the medium- and low-propensity groups, an IMF program is associated with an improvement in income distribution.

In summary, this review of the literature on Fund programs highlights both substantive conclusions and methodological issues. On substance, Fund programs help with respect to the current account and the balance of payments. Thus, net capital flows should decrease following the start of a Fund program. With respect to gross flows also, the literature has generally concluded that no IMF catalytic effect exists. Methodologically, the literature points to concerns with regard to counterfactuals, reverse causality, and omitted variables that affect both program participation and capital market access.

\section{Methodology and Data}

In this paper, we move away from using volumes of gross capital flows and focus instead on the probability of bond issuance in international markets and the spreads charged on individual bonds. In thus limiting our focus, we do not consider other forms of capital flows, such as syndicated loans and foreign direct investment. However, flows through bond issuance were a major source of international capital to emerging markets in the $1990 \mathrm{~s}$. The spotlight on the available transactional bond data improves, we believe, the prospects of addressing both substantive and methodological issues. In this section, we first present our basic framework for analyzing the determinants of bonds issuance and spreads. We then discuss our approach to dealing with the econometric concerns highlighted by the literature review. Finally, we present some descriptive statistics.

\section{A. Framework for Analyzing Spreads}

We adopt an estimation approach developed in earlier papers (see Eichengreen and Mody, 2001). We estimate a two-equation model: the "spreads" equation, which specifies the determinants of spreads charged on a particular bond, and the "selection" equation, which is a probit for the decision to issue the bond. Throughout, the spread we use is the so-called primary or launch spread and is defined as the premium paid at the time of bond issuance over the risk-free rate for a bond of similar maturity and currency denomination. Because we use primary spreads, we do not "follow" a particular bond "over time." Bond frequency issuance varies over time, resulting in varying numbers of bonds for a given country in any given time period.

The spreads equation is a linear relationship:

$$
\log (\text { spread })=\beta X+u_{l}
$$

where the dependent variable is the logarithm of the spread; $X$ is a vector of issue, issuer, and period characteristics; and $u_{I}$ is a random error. The $X$ vector contains a dummy variable for an IMF program, other program characteristics, and also interactions between the program and country characteristics, as we discuss below in detail. Since the spread will be observed only when the decision to borrow and lend is made, we correct for this sample selection 
problem. Assume that spreads are observed when a latent variable $B$ crosses a threshold $B^{\prime}$ defined by:

$$
B^{\prime}=\gamma Z+u_{2}
$$

where $Z$ is the vector of variables that determines the desire of borrowers to borrow and the willingness of lenders to lend (and will also contain the IMF program variables and their interactions), and $u_{2}$ is a second error term. We further assume that:

$$
\begin{aligned}
& u_{1} \sim N(0, \sigma) \\
& u_{2} \sim N(0,1) \\
& \operatorname{corr}\left(u_{1}, u_{2}\right)=\rho
\end{aligned}
$$

This is a sample selection model à la Heckman (1979) and equations (1) and (2) can be estimated simultaneously by a maximum likelihood procedure. Estimating the determinants of market access requires information on those who did not issue bonds. For each country we consider three categories of issuers: sovereign, (other) public, and private. For each quarter and country where one of these issuers did not come to the market, we record a zero, and where they did we record a one.

Leung and $\mathrm{Yu}(1996)$ note that the estimation does not require the variables in the selection equation and the spread equation to be different. What is critical instead is to avoid multicollinearity between the variables in the spreads equation and the "inverse-Mills ratio" constructed from the selection equation. That, in turn, requires the value of the variables not be concentrated in a small range and that the truncated observations (no bond issuance) should not dominate the set of observations. In our case, most variables have a large range and about a third of the observations have a bond issued. We do include in the selection equation (the probit), the ratio of debt service to exports, which appears to influence the issuance decision but not the determination of spreads. ${ }^{13}$

The data sources for the dependent and explanatory variables are documented in Appendix I. Details on bonds issued and their characteristics are obtained from Bondware, a commercial data source. Bond characteristics included in the spreads equation are: the dollar value of the

${ }^{13}$ Dell'Ariccia, Godde, and Zettelmeyer (2000) follow a similar research strategy but also add as instruments in the probit equation the bonded debt issued in the previous year, the number of bonds issued in the previous year, the natural logarithm of per capita GDP in 1993, and a dummy variable for countries directly affected by the Asian crisis. Ideally, the instruments should influence the issuance decision but not the spreads. It is not obvious that these four variables fulfill that objective and, in practice, it is hard to find such variables. For example, Asian-crisis countries were rationed during specific years but also paid higher spreads in those years. Hence, it is not sufficient to rely on exclusion conditions. 
bond issued, its maturity, whether the issuer was in the public or private sectors, the industrial sector of the issuer, the currency of issue, and whether the bond had a fixed or floating rate.

The global variables included in both the spreads and selection equation are: U.S. industrial growth rate during the quarter in which the bond was issued; the daily swap rate (as a measure of liquidity risk); and, as a measure of market uncertainty, the standard deviation of daily Emerging Market Bond Index (a commonly followed index of emerging market spreads) over the relevant quarter.

In the spreads equation, we use the following country characteristics as control variables: country credit ratings provided by Institutional Investor, external debt relative to GNP, a dummy variable for whether the sovereign has restructured debt within the previous year, the growth rate of real GDP, the variance of export growth, the ratio of short-term debt to total debt, the ratio of reserves to imports, and the ratio of domestic private credit to GDP. Note that the debt-restructuring variable we use is not the same as debt rescheduling: restructuring reflects a positive effort at debt management and typically involves exchange new debt for old more expensive or inflexible debt. Also, while it is common to use the ratio of reserves to short-term debt as a measure of country liquidity, we use short-term to total debt and reserves to imports since we want to examine separately the influence of short-term debt and reserves.

The IMF variables we use in alternative specifications in the spreads and selection equation are: IMF program dummy, a measure of repeated Fund programs, the size of the program relative to the country's external debt, and whether a program was "precautionary," that is, if in practice there was no, or limited, drawing down of Fund resources. The onset of the Fund program was dated by the month in which it originated, which contrasts with the typical practice of using an annual dummy variable if a program was initiated at any time during the year. Dicks-Mireaux, Mecagni, and Schadler (2000) note that the timing of IMF programs makes a difference to the empirical results. In their analysis, they code the IMF dummy variable to take the value one if a program was in effect for six or more months during the year. Kaminsky and Schmukler (1999) use daily announcements to track movements in stock markets and find, on average, that stock markets respond positively on the days agreements are reached with international organizations such as the IMF. We believe that the more precise timing of programs in this paper helps with reducing the reverse-causality problem.

\section{B. Evaluating IMF Programs: Econometric Issues}

The literature review has highlighted the need to: (1) identify the direction of causality; and (2) consider the possibility of omitted variables bias (of which, as we discuss below, selection bias is a special case). ${ }^{14}$

${ }^{14}$ The mean-reversion problem does not apply in our case. That problem arises when the change in the indicator of interest is the dependent variable. The extent of the change, it is argued, depends among other things on the initial level of the indicator. In our case, we are not examining changes in spreads but rather the level of spreads in any period. 
Consider first the identification issue. In a recent paper, Barro and Lee (2001) use as instruments for participation in Fund programs, such variables as the political affinity of the country to the United States, the national composition of the Fund's staff, and past participation in Fund programs. ${ }^{15}$

The reverse-causality problem, we believe, is less serious in our case than for those who have addressed this issue in the past. All previous studies use data at frequencies of at least one year (Barro and Lee, 2001, use five-year averages). Moreover, the outcomes they test (such as growth, current account balances, inflation) are national outcomes just as the IMF program is a national decision. It is quite likely that over these time spans, and especially as the time span gets longer, national economic outcomes will influence the decision to participate in Fund programs.

In our case, there are two key differences relative to the past literature. First, the outcome we observe is an individual bond issue. While a bond issue may be large and reflect broad market sentiment towards the country, a single bond issue is unlikely to trigger an IMF program. And this leads to our second point. Our observations are at a much higher frequency than is the case with past studies. Figure 1 shows that if the IMF program is initiated at the time shown by the solid vertical line but the dotted line is the starting date that the econometrician uses, then we are likely to find a positive correlation between IMF programs and spreads, reflecting reverse causation. However, if we take the actual, or more accurate starting time, then we are more likely to observe whether a Fund program was associated with a reduction in spreads. A bond issuance is recorded on the day it occurs and the start of an IMF program is recorded in our data in the month in which it occurs. Since the actual start of a program reflects many considerations, including negotiations between a country and the Fund and internal Fund procedures, this further reduces the likelihood that there is significant feedback from an individual transaction to an IMF program. As it turns out, the sign on the coefficient of the IMF program in the spreads equation is typically negative, implying that a Fund program is, all else equal, associated with lower spreads. Thus, if poor market sentiment towards a country leads to a Fund program, then our result suggesting that a Fund program lowers spreads would only be strengthened.

Figure 1 also points to the importance of controlling for variables that move the level of spreads: thus the rise in spreads before the onset of a Fund program could reflect worsening of country characteristics, which could be misattributed to the Fund program. This further concern with respect to omitted variables is often stated as a "selection bias" problem and the Heckman selection correction is sometimes applied. However, as the literature review has shown, Fund programs are in place in a variety of circumstances that are not easily captured through a probit equation that forms the first step of the selection bias correction. Edwards

${ }^{15}$ It is not clear that past participation in Fund programs is a good instrument since it could reflect unobserved country characteristics that constrain the country's economic growth. In that case, some part of the country's low economic growth will be attributed to the Fund. 
(2000) finds that correction for selection bias does little to change his results. With our higher frequency data, predicting Fund programs is likely to be even more difficult (not least because the right-hand-side variables are often measured at much lower frequencies). In addition, a variable that consistently works well in predicting participation in Fund programs is past participation (see Barro and Lee, 2001, and Bagci and Perraudin,1997). If this is a key omitted variable, then it appears to us that the best approach is to include it directly in the outcome equation. Indeed, our results below show that the history of past participation in Fund programs has a significant bearing on capital market access. In addition, we include some nonlinear terms that also could proxy for some omitted variables.

\section{Descriptive Statistics}

Between 1990 and 2000, over $250 \mathrm{IMF}$ programs were negotiated, with the number of programs varying between 20 and 35 a year, except in 1990 and 2000 when there were less than 20 programs. There is no trend in either the number of programs or the amount of financial support committed by the Fund. In particular, financial support has been large at times of crises: the big jump in 1995 reflects the large package to Mexico and the large commitments in 1997 and 1998 followed the East Asian and Russian crises.

Table 2 shows that between 1991 and 2000, the period covered by this paper, about one-third of all developing country and emerging market bonds were issued by borrowers from countries with IMF programs. ${ }^{16}$ The spreads charged (yield to maturity minus the risk-free rate) on the bonds were typically higher for program countries (406 basis points) compared with countries that did not have such programs at the time the bonds were issued ( 223 basis points). Also, bonds issued by program countries had shorter maturities ( 5.44 years versus 6.67 years).

It was thus the case that IMF programs were associated with poorer access terms. ${ }^{17}$ This is not surprising, since Fund programs were also associated with worse fundamentals: higher debt/GDP ratios, lower recent growth, and greater volatility. Countries with Fund programs appear to have better credit quality in one dimension: among those that issued bonds, those with Fund programs have higher reserves. Also, issuers with Fund programs have had lower ratios of short-term debt to total debt; however, that may reflect their lack of access to shortterm credit. In the next section, we examine the relationship between Fund programs and capital market access after controlling for country fundamentals-and also for bond characteristics and global fundamentals.

${ }^{16}$ Of the 3,295 bonds issued during this period, spreads are available on 3,066 bonds. We "lose" another 76 bonds due to absence of complementary information. The ratio of bonds issued by countries in IMF programs is almost the same whether we consider all bonds or only those that have the necessary information required for the analysis.

${ }^{17}$ Though the average size of a bond issue is somewhat higher when a country is in a Fund program than when it is not. 


\section{The Role of Country Fundamentals}

We begin with the conventional approach representing an IMF program as a dummy variable signifying whether an IMF program was ongoing or not. Then we explore the influence of the country's external vulnerability by interacting the IMF program dummy with a variety of country characteristics. As noted above, we jointly estimate the decision to issue a bond and the determination of the spread on the bond. A complete set of results for the base equation is reported in Appendix II. In the rest of this paper, we continue to use the controls in this base equation but, to conserve space, we report only the coefficients on the relevant IMF variables and their interactions with other determinants of bond issuance and spreads.

Column 1 in Table 3 shows the simple effect of the Fund's presence at the time of bond issuance. Fund presence is seen in the selection equation to significantly improve market access, raising the frequency of bond issuance. Fund programs are also associated with reduced spread. The point estimate suggests that the presence of a Fund program reduces spreads by about 10 percent. If there were mainly "reverse" causation, with periods of market aversion to a country causing a Fund program, we would have found the coefficient on the Fund program dummy to be negative in the selection equation and to be positive in the spread equation. If we repeat this regression with all control variables other than the country characteristics (i.e., if we keep the bond features and the global variables but drop the country controls such as the debt to GDP ratio), then we do find that the IMF dummy is negative and highly significant in the selection equation and positive and significant in the spreads equation, a result, which if true, would imply that Fund programs hurt the ability to access markets. Clearly, the failure to control for the country variables results in this misattribution of the country weakness to IMF programs. The omission of relevant country controls in some of the studies cited above could be the reason for their reaching a bleaker conclusion on IMF programs than is warranted.

We next examine how IMF programs interact with country characteristics. The first question we ask is whether a Fund program is helpful in dampening the effect of external volatility (Table 3, Column 2). We use a measure of the volatility of the country's exports (the standard deviation of the monthly growth of exports). When entered independently, this measure is associated with higher spreads and lower probability of bond issuance suggesting that volatility shifts the supply of funds to the left (see Appendix II). This is consistent with the Catao and Sutton (2002) finding that under conditions of macroeconomic volatility sovereign debt defaults are more likely and hence will result in reduced access and higher spreads. When we interact export volatility with the IMF program dummy, the interaction term enters with a negative and significant sign. Thus, absent a Fund program, an increase in volatility from the median to the $75^{\text {th }}$ percentile raises spreads by 6.5 percent; with a Fund program, that increase is only 2 percent. The evidence supports the possibility, discussed above, that the Fund program acts a commitment mechanism that counteracts the effect of volatility. Viewed alternatively, the result indicates that an IMF program is particularly beneficial as country volatility increases, reducing spreads and increasing the probability of bond issuance. The effects are not small. At the median volatility, an IMF program is associated with a 7.4 percent reduction in spreads but at the $75^{\text {th }}$ percentile of volatility, 
spreads are lower by 12.0 percent. Thus, once again, where volatility is high, the presence of the $\mathrm{MF}$ acts to reduce investor aversion to the country.

But the Fund is not able to counteract all types of volatility. The interaction, for example, of Fund programs with the volatility of the Emerging Market Bond Index (the EMBI) is statistically insignificant in the selection and spreads equation, suggesting that a country with a Fund program is not insulated from high volatility in international capital markets.

We next consider the possibility that IMF programs are most effective when countries are vulnerable but not without hope of return to normalcy. This could be the case, as discussed above, if contracting and information problems are especially severe in periods of vulnerability. The goal is to determine if the credibility of joint commitment is eroded if country fundamentals are past the point of early remedial action. We examine the effectiveness of IMF programs with respect to the availability of reserves (proxied by the ratio of reserves to imports) and the country's external debt-to-GDP ratio. A simple interaction of the IMF program dummy and reserves/imports showed no statistical effect. Thus, we were led to consider the possibility that IMF programs may interact with reserves availability (and other domestic conditions) in a nonlinear manner. In other words, could it be that countries with very high or very low reserves do not benefit from IMF programs but those in the middle do?

To examine the nonlinearity, we specified a piece-wise linear function. ${ }^{18}$ We split the reserves-to-imports ratio at the median, creating two variables: the reserves-to-imports in the low range and in the high range. Column 3 of Table 3 reports the coefficients for the IMF dummy intercepts and the interaction terms for low and high ranges of country reserves-toimports. ${ }^{19}$ For countries with low reserves, the results suggest that spreads are higher with a program rather than without a program. The IMF effect improves with reserve availability and a Fund program turns beneficial when the reserves cover at least 3 months of imports. At the median value of reserves to imports (about 4.5 months of imports), the effective coefficient on the Fund program is -0.19 , that is, a Fund program lowers spreads by about 19 percent. However, past the median value of reserves to imports, the Fund effect worsens again, and turns to a small positive effect on spreads when reserves are larger than about a year's worth of imports. The effects on probability of issuance are also nonlinear and we find, in particular, that the IMF's assistance in improving the probability of issuance declines rapidly after the median value of reserves-to-imports, though the magnitude of the effects are not large in this case.

${ }^{18}$ While this approach imposes considerable structure, it allows a simple test of the possibility that country conditions matter in a nonlinear manner. Adding a quadratic interaction term was not feasible because of a multicollinearity problem.

${ }^{19}$ The full equation, which is not reported here, now has two variables representing reserves to imports in the low and high ranges. 
The evidence, therefore, suggests that if a country's reserves are very low, Fund programs are unable to compensate for the economic difficulties faced by the country. In contrast, when reserves are low-but have not yet fallen to the extremely low levels that signify deeper structural problems-Fund programs can be very effective. The results further suggest that as reserves increase Fund effectiveness falls off, as may be expected. But a point may also be reached where Fund programs may come in the way of market access if undertaken when reserves are high--as if the presence of an ambulance is a sign of trouble.

We repeated the same methodology with debt-to-GNP ratio, with similar results. ${ }^{20}$ Thus, once more we created two variables, one with the debt-to-GNP ratio in the low range (below its median value) and another in the high range. We interacted these two variables with the IMF dummy to test if these interactions vary with the range in which the debt-to-GNP ratio falls. The results support the analysis above. The estimates presented in Column 4 of Table 3 imply that IMF programs are effective in reducing spreads when the debt-to-GNP ratios are between 34 and 61 percent. For debt-to-GNP, interactions with IMF programs are also strongly nonlinear in influencing the probability of issuance, with the favorable effects on issuance lying in the range of 25 to 63 percent. Interestingly, Pattillo, Poirson, and Ricci (2002) find that an external-debt-to-GDP ratio of about 35 percent marks the threshold beyond which additional debt accumulation has a negative effect on growth. This threshold is at the lower end of our estimated range in which the Fund has a catalytic effect. Thus, once a country has crossed the threshold, the Fund can counteract the negative impact of the high level of debt, but at a diminishing rate.

In summary, the results clearly support the idea that country fundamentals matter in determining the effects of Fund programs. These programs help when the country's export composition makes it is prone to external volatility. However, along other dimensionsreserves and debt---poor country fundamentals can hurt. It is as if the credibility of Fund programs is weakened when the country has already placed itself in a highly vulnerable external position. Instead, the Fund is effective when countries are in the early stages of external payment difficulties and the restoration of the imbalance has a reasonable likelihood.

\section{Implications of Fund-SupPorted Program Design}

In this section, we explore three dimensions of IMF programs: (1) size of lending (normalized by country debt); (2) whether a program was "precautionary" or not; and (3) "prolonged" use of Fund resources.

The Fund can signal the credibility of a stabilization process and its intention to support that process not just through its presence but also through the size of the program. In Column 1 of Table 4, we replace the IMF program dummy with the amount committed (as a percentage of the country's long-term debt). The results show that program size is important. Larger programs both increase the probability of bond issuance and lower spreads. The results imply

${ }^{20}$ Results were similar also when considering short-term to total debt. 
that an additional program size equal to 10 percent of the country's long-term debt lowers spreads by about 13 percent.

Why would a larger program size have a greater catalytic effect? It could be that investors view the country's repayment capacity to have improved when IMF funds become available. However, while repayment difficulties may be relieved in the short term, over a more medium term, the Fund also has to be repaid and so, over that longer time horizon, the country's repayment capacity is not improved by the mere fact of an IMF loan. Moreover, to the extent, the IMF is a preferred creditor, it is possible that some private creditors may take the view that their repayment prospects have in fact become worse. Thus, if it were mainly the case that the amounts received from the Fund were helping repay existing debt, access to new debt should not improve and spreads on that new debt should not decline. An alternative interpretation of the better market access is that the size of the Fund program signals greater commitment to economic reforms that, in turn, improves the more medium-term capacity of the country to honor new contractual obligations.

The amount committed in a Fund program is not necessarily disbursed-programs may bc "precautionary." Programs may be precautionary in two senses. First, at the time the program is agreed upon, the borrowing country may declare its intention to not draw on the resources made available. While this is not a contractually binding restriction, and the country can change its mind with no penalty, declaration of the intent to not borrow implies that Fund resources are not critical. Rather the country is volunteering to subject itself to the discipline of the Fund's program. Second, the country may negotiate a Fund program and draw on Fund resources initially but thereafter voluntarily halt disbursements while keeping the IMF program in place. Yet, by its later action of not drawing on the resources, the country may treat the program as precautionary. Such programs may be referred to as "turned precautionary."21 Programs that "turn" precautionary are larger in size than the "outset" precautionary programs and, presumably, have more demanding policy conditionality. Of the 245 programs between 1991 and 2000 covered in this analysis, only 38 were precautionary at the outset and 13 "turned" precautionary. However, of the bonds issued while a country was in a Fund program, over 45 percent were during precautionary programs (18 percent were precautionary at outset and 33 percent "turned" precautionary).

How do precautionary programs fare? Column 2 of Table 4 shows that precautionary programs of the two varieties ("outset" and "turned" precautionary) have differing implications. The results suggest that "declared" precautionary programs do not have a significant effect over and above that already implied by the presence of the program and the program size (as reflected in the variable representing the IMF committed amount/the country's debt level). In contrast, turned precautionary programs add significantly to the value of the IMF's presence both in terms of spreads and access.

${ }^{21}$ The country chooses to continue the arrangement and pay the commitment fee rather than simply canceling it. 
Recall, that "turned" precautionary programs are significantly larger than the "outset" precautionary programs. ${ }^{22}$ Thus, the highly significant sign on the "turned" precautionary dummy reflects the benefits deriving both from the precautionary nature of the program and the large resource size associated with it. Thus, the size of the amount coefficient falls from 1.28 to 0.82 . The evidence suggests, therefore, that those subjecting themselves to the Fund's discipline can benefit even when the resources are not drawn - the available cushion helps.

There is yet another Fund facility that combines large resource size and precautionary intent. This is the "Supplemental Reserve Facility (SRF)," that has been used for large-sized programs at times of crises. The premise is that country in the midst of a crisis is subject to a loss of confidence even though the fundamentals are relatively sound. The goal thus is to bring back confidence to the country and, at the same time to prevent "contagion" or the loss of confidence from spreading to other countries. The SRF overlaps to a considerable extent with programs that turned precautionary. ${ }^{23}$ As such, in Column 3 of Table 4, we find that while the sign on the IMF amount, the dummy variable for the SRF, and the dummy variable for "turned precautionary" programs are all negative, their significance is marginal. When we repeat the regression without the IMF amount (Column 4), both the SRF and the "turned precautionary" programs come in with significantly negative signs in the spreads equation and positive signs in the selection equations.

These findings can be linked back to our discussion of country fundamentals. Though the fundamentals in countries with "turned precautionary" programs are worse than in nonprogram countries, they are superior to those in countries with other forms of IMF programs. In particular, "turned precautionary" countries do better than other program countries with respect to lower debt/GDP ratios, higher growth, and lower volatility. In contrast, their reserves/import ratios are not very different from those in countries with other programs. Thus, an interpretation of our results is that "turned precautionary" countries are vulnerable to external pressures and that the vulnerability has further led to a liquidity problem.

However, because the underlying fundamentals are not yet beyond a point of no return in the short-run, a reform program with IMF support carries credibility.

Finally, we ask if there may be diminishing returns to a country's repeated interactions with the Fund. Two opposing forces may be at work here. Repeated Fund involvement may be warranted in light of medium-term problems that the country faces and may reflect a joint commitment on the part of the country and the Fund to resolve the problems. However, it may be the case that "prolonged" use of Fund resources implies an inability to resolve the problems at hand and is an indicator, therefore, of more deep rooted problems. The term

${ }^{22}$ The median size of "outset" precautionary programs is about 40 million SDRs whereas that for "turned" precautionary programs is almost 10 times larger at 330 million SDRs. When normalized by country debt, the "turned" precautionary programs are still much larger.

${ }^{23}$ The analysis here includes those loans that were made under "exceptional circumstances" and were thus similar in intent to the SRF. 
"prolonged" use has many different indicators but one of them recently proposed by the IMF's new Independent Evaluation Office is the existence of a program for more than 70 percent of the time over a given period.

Thus, we examine if repeated Fund presence in a country makes a difference to its effectiveness in this non-linear manner. The measure of repeated Fund presence we use is the number of months that a Fund program was in place in the country just prior to the start of the $1990 \mathrm{~s}$, during the four-year (48-month) period from 1987 to 1990 . Use of a prior time period ensures that we do not pick up a reverse causation from poor market access to a high frequency of Fund programs. It turns out that there is a high correlation between the number of months the country had a program in the late 1980s and the number of months a program was in place in the 1990s. This persistence suggests that our measure of the Fund's ongoing involvement in a country reflects a combination of continuing economic difficulties and the inability of the Fund and the country to work together to achieve the necessary reforms. Since we have already controlled for external indicators such as debt and reserves, the number of months that the Fund program was in place in the late 1980s proxies for these other (unobserved) country characteristics and the Fund-country relationship. With this interpretation in mind, the result supports the speculation above (see Column 5). Continued Fund presence helps up to a point. These results suggest that the "turning point" is at about 18 months out of the 48-month window over which our measure of repeated interaction is taken. Beyond that length of time, continuing Fund effectiveness in helping with market access begins to decline and at about 32 months, or about 75 percent of the time window, continued presence raises spreads. At that point, investors apparently believe that the problems are either deep-rooted or that the Fund is unable to exercise the necessary influence to resolve them. These results and interpretation are consistent with Conway's (2001) conclusion that a continuing Fund-country relationship reaches diminishing returns.

To summarize the findings in this section, the evidence suggests that constructive engagement between the Fund and the member country can be demonstrated in different ways. Credibility is established by the size of the program, and thus resources made available do matter. However, the results also show that large Fund resources and voluntary country commitment under so-called "turned" precautionary programs go together in signaling both country intentions and Fund discipline. The programs under the Supplemental Reserve Facility (SRF) have also been of this nature, but the SRF has not been the only vehicle to establish confidence by committing significant resources that are ultimately not used. Finally, where Fund programs are frequently repeated, the credibility of effective reforms seems to be called into question by the market.

\section{Conclusions}

Except for some recent efforts to distinguish between programs in terms of their degree of compliance with agreed policy initiatives, the vast bulk of the empirical literature does not distinguish between one program and another-each program takes an undistinguishable value of 1 in the program dummy variable. This paper takes seriously the diversity in Fund programs and demonstrates that they do vary significantly in their effects. Country 
fundamentals and program design differ widely across programs and, not surprisingly, these do have a bearing on the outcomes.

Thus, a Fund program is not an automatic or standardized "good housekeeping seal of approval." ${ }^{24}$ Investors appear to value the Fund's participation in resolving the country's external payment difficulties but only when they view it is as likely that the effort will be successful. ${ }^{25}$ Our further contribution, we believe, is to suggest the conditions under which programs are likely to succeed. Successful outcome, measured in this paper as improved access to international markets, depends on the market's perception of credible reform measures.

The interplay of country fundamentals with IMF programs also points to the importance of the credibility of reform measures. Here our finding is that the Fund can help mitigate the market's aversion to volatility of export growth, acting as if to bolster a country's reserves. The market apparently discounts stated efforts to undertake reform and, indeed, countries with weak external payments positions could adopt risky strategies to overcome their problems, hence deviating from the course of action agreed on with the Fund.

Large program size can help signal stronger commitment on the part of the country and the Fund, but it appears the program-size effect weakens when the effect of "precautionary" programs is considered. Precautionary programs help boost the frequency of market access and, especially the programs that turn precautionary-which are also much larger in size than those declared precautionary at the outset - help significantly reduce spreads. Thus, both the voluntary nature of inviting Fund discipline and the potential for drawing on resources, if needed, help improve market access. Repeated use of Fund programs sends a bad signal in this respect. The implication of our results is that where programs are repeated often, the

${ }^{24}$ The gold standard, which apparently did provide a "good housekeeping seal," was associated with a narrow range of prudential macroeconomic policies (Bordo and Rockoff, 1996). In contrast, the current range of IMF member countries - and the variety of economic challenges facing them-leads to a much larger variation in appropriate economic policy measures. Obstfeld and Taylor (2002) conclude even in the case of the gold standard that its credibility was diminished in the interwar period (1925-31) and unlike Bordo, Edelstein, and Rockoff (1999), they find that only those who devalued before reentering the gold standard benefited in the form of lower spreads. The implications of the Obstfeld and Taylor analysis is, thus, similar to ours: country conditions matter in determining the credibility of policy actions.

${ }^{25}$ It is not straightforward to distinguish a "good" catalytic effect from a "bad" one in which moral hazard predominates. We find that Fund effectiveness in catalyzing flows declines as the country's own repayment capacity becomes less credible, which suggests that moral hazard is not dominant. Moreover, moral hazard is likely to reflect itself in cross-country effects rather than a renewed burst of imprudent lending to the country that enters into a Fund program (Lane and Philips, 2000). 
markets infer additional problems that are not reflected in the most commonly observed indicators of country solvency and liquidity. 
Table 1. Frequency of IMF Programs

Number of Programs per year (Size of programs in billions of SDRs)

\begin{tabular}{lcccc}
\hline & SBA & EFF & ESAF & Total \\
\hline 1990 & 12 & 0 & 3 & 15 \\
& $(1.70)$ & $(0)$ & $(0.56)$ & $(2.25)$ \\
1991 & 19 & 2 & 8 & 29 \\
& $(5.30)$ & $(2.34)$ & $(0.69)$ & $(8.33)$ \\
1992 & 15 & 4 & 6 & 25 \\
& $(2.74)$ & $(4.59)$ & $(0.44)$ & $(7.78)$ \\
1993 & 13 & 2 & 7 & 22 \\
& $(1.64)$ & $(1.42)$ & $(0.28)$ & $(3.34)$ \\
1994 & 18 & 4 & 13 & 35 \\
& $(2.61)$ & $(1.49)$ & $(2.19)$ & $(6.29)$ \\
1995 & 21 & 2 & 7 & 30 \\
& $(19.09)$ & $(1.28)$ & $(1.20)$ & $(21.57)$ \\
1996 & 12 & 6 & 14 & 32 \\
& $(3.52)$ & $(14.25)$ & $(1.30)$ & $(19.07)$ \\
1997 & 10 & 4 & 7 & 21 \\
& $(28.02)$ & $(1.03)$ & $(1.37)$ & $(30.42)$ \\
1998 & 6 & 4 & 11 & 21 \\
& $(11.71)$ & $(10.01)$ & $(1.06)$ & $(22.77)$ \\
1999 & 7 & 4 & 9 & 20 \\
& $(9.94)$ & $(2.80)$ & $(0.86)$ & $(13.60)$ \\
2000 & 10 & 2 & 0 & 12 \\
& $(7.36)$ & $(3.66)$ & 0 & $(11.02)$ \\
$\mathbf{1 9 9 0 - 2 0 0 0}$ & $\mathbf{1 4 3}$ & $\mathbf{3 4}$ & $\mathbf{8 5}$ & $\mathbf{2 6 2}$ \\
& $(\mathbf{9 3 . 6 2 )}$ & $\mathbf{4 2 . 8 7 )}$ & $(\mathbf{9 . 9 5})$ & $\mathbf{( 1 4 6 . 4 5 )}$ \\
\hline & & & &
\end{tabular}

Note: SBA is for Stand-By Arrangement; EFF is for Extended Fund Facility; and ESAF is for Enhanced Structural Adjustment Facility (includes Structural Adjustment Facility and the now renamed Poverty Reduction Growth Facility). 
Table 2. Bond Issuance, Terms, and Country Characteristics

\begin{tabular}{|c|c|c|c|}
\hline & $\begin{array}{r}\text { No } \\
\text { Program }\end{array}$ & $\begin{array}{r}\text { Fund } \\
\text { Program }\end{array}$ & Total \\
\hline & \multicolumn{3}{|c|}{ A: Bond Issued } \\
\hline Number of bonds & 2156 & 1139 & 3295 \\
\hline Spread (basis points) & 223 & 406 & 282 \\
\hline Maturity (years) & 6.67 & 5.44 & 6.25 \\
\hline Amount ( $\$$ millions) & 154 & 177 & 162 \\
\hline Debt/GDP & 0.27 & 0.43 & 0.32 \\
\hline Annual GDP growth (percent) & 5.04 & 3.29 & 4.40 \\
\hline Short-term/total debt & 0.66 & 0.50 & 0.56 \\
\hline Reserves/imports (months of imports) & 5.91 & 6.78 & 6.21 \\
\hline \multirow[t]{2}{*}{ Volatility of exports } & 0.08 & 0.11 & 0.09 \\
\hline & \multicolumn{3}{|c|}{ B: No Bond Issued } \\
\hline Debt/GDP & 0.39 & 0.56 & 0.46 \\
\hline Annual GDP growth (percent) & 4.00 & 2.65 & 3.30 \\
\hline Short-term/total debt & 0.55 & 0.49 & 0.52 \\
\hline Reserves/imports (months of imports) & 4.89 & 4.68 & 4.83 \\
\hline Volatility of exports & 0.14 & 0.18 & 0.16 \\
\hline
\end{tabular}


Table 3. Interaction of Country Characteristics with Fund Programs

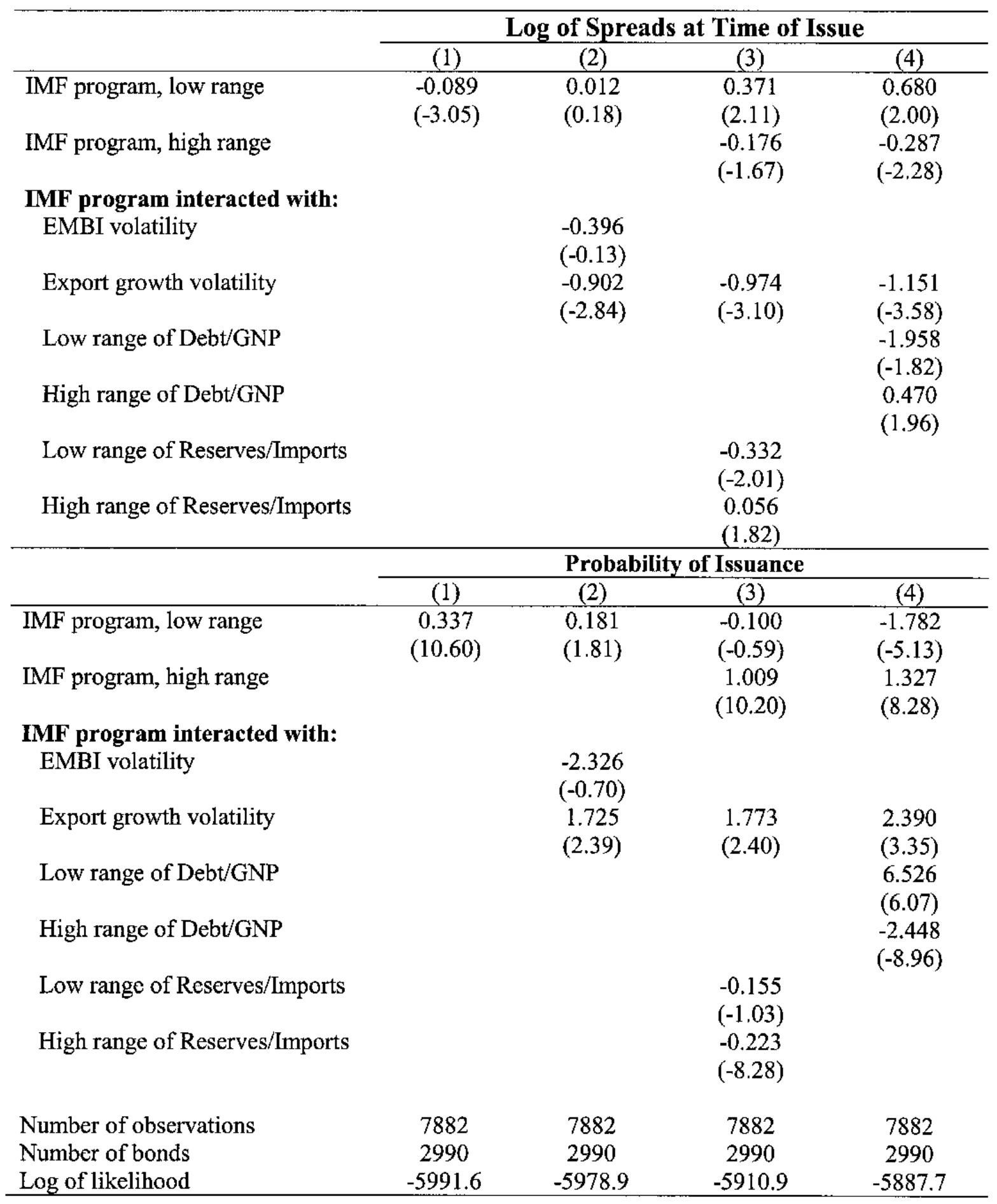

Note: These regressions all have bond, global, and country controls as specified in the full regression presented in Appendix II.

z-statistics, based on robust standard errors, are presented in the parentheses. 
Table 4. Influence of Program Features on Bond Market Spreads and Issuance

\begin{tabular}{|c|c|c|c|c|c|}
\hline & \multicolumn{5}{|c|}{ Log of Spreads at Time of Issue } \\
\hline & (1) & (2) & (3) & (4) & (5) \\
\hline IMF amount/debt & $\begin{array}{l}-1.290 \\
(-3.62)\end{array}$ & $\begin{array}{l}-0.825 \\
(-2.38)\end{array}$ & $\begin{array}{l}-0.554 \\
(-1.55)\end{array}$ & & $\begin{array}{l}-1.328 \\
(-3.61)\end{array}$ \\
\hline \multicolumn{6}{|l|}{ Precautionary program: } \\
\hline Outset & & $\begin{array}{c}0.021 \\
(0.38)\end{array}$ & $\begin{array}{l}0.001 \\
(0.01)\end{array}$ & $\begin{array}{l}-0.019 \\
(-0.34)\end{array}$ & \\
\hline Turned & & $\begin{array}{l}-0.139 \\
(-3.58)\end{array}$ & $\begin{array}{l}-0.091 \\
(2.13)\end{array}$ & $\begin{array}{l}-0.101 \\
(-2.34)\end{array}$ & \\
\hline Supplemental Reserve Facility & & & $\begin{array}{l}-0.119 \\
(-1.98)\end{array}$ & $\begin{array}{l}-0.161 \\
(-2.73)\end{array}$ & \\
\hline Number of months in IMF program, 1987-90 & & & & & $\begin{array}{l}-0.029 \\
(-5.92)\end{array}$ \\
\hline \multirow[t]{3}{*}{$\begin{array}{l}\text { Square of Number of months in IMF program, } \\
1987-90\end{array}$} & & & & & $\begin{array}{l}0.001 \\
(5.92) \\
\end{array}$ \\
\hline & \multicolumn{5}{|c|}{ Probability of Issuance } \\
\hline & (1) & (2) & (3) & (4) & (5) \\
\hline $\mathrm{IMF}$ amount/debt & $\begin{array}{c}5.659 \\
(16.57)\end{array}$ & $\begin{array}{c}4.940 \\
(13.02)\end{array}$ & $\begin{array}{l}3.623 \\
(8.56)\end{array}$ & & $\begin{array}{c}5.945 \\
(16.84)\end{array}$ \\
\hline Precautionary program: & & & & & \\
\hline Outset & & $\begin{array}{l}-0.091 \\
(-1.40)\end{array}$ & $\begin{array}{l}-0.053 \\
(-0.83)\end{array}$ & $\begin{array}{l}0.002 \\
(0.04)\end{array}$ & \\
\hline Turned & & $\begin{array}{l}0.253 \\
(5.24)\end{array}$ & $\begin{array}{l}0.145 \\
(2.44)\end{array}$ & $\begin{array}{l}0.211 \\
(3.51)\end{array}$ & \\
\hline Supplemental Reserve Facility & & & $\begin{array}{l}0.464 \\
(5.57)\end{array}$ & $\begin{array}{c}0.818 \\
(10.55)\end{array}$ & \\
\hline $\begin{array}{l}\text { Number of months in IMF program, } \\
1987-90\end{array}$ & & & & & $\begin{array}{c}0.065 \\
(16.94)\end{array}$ \\
\hline $\begin{array}{l}\text { Square of Number of months in IMF program, } \\
1987-90\end{array}$ & & & & & $\begin{array}{l}-0.002 \\
(-15.40)\end{array}$ \\
\hline Number of observations & 7882 & 7882 & 7882 & 7882 & 7882 \\
\hline Number of bonds & 2990 & 2990 & 2990 & 2990 & 2990 \\
\hline Log of likelihood & -5957.1 & -5948.1 & -5940.2 & -5956.1 & -5841.3 \\
\hline
\end{tabular}


Figure 1. Econometric Implications of Timing IMF Programs

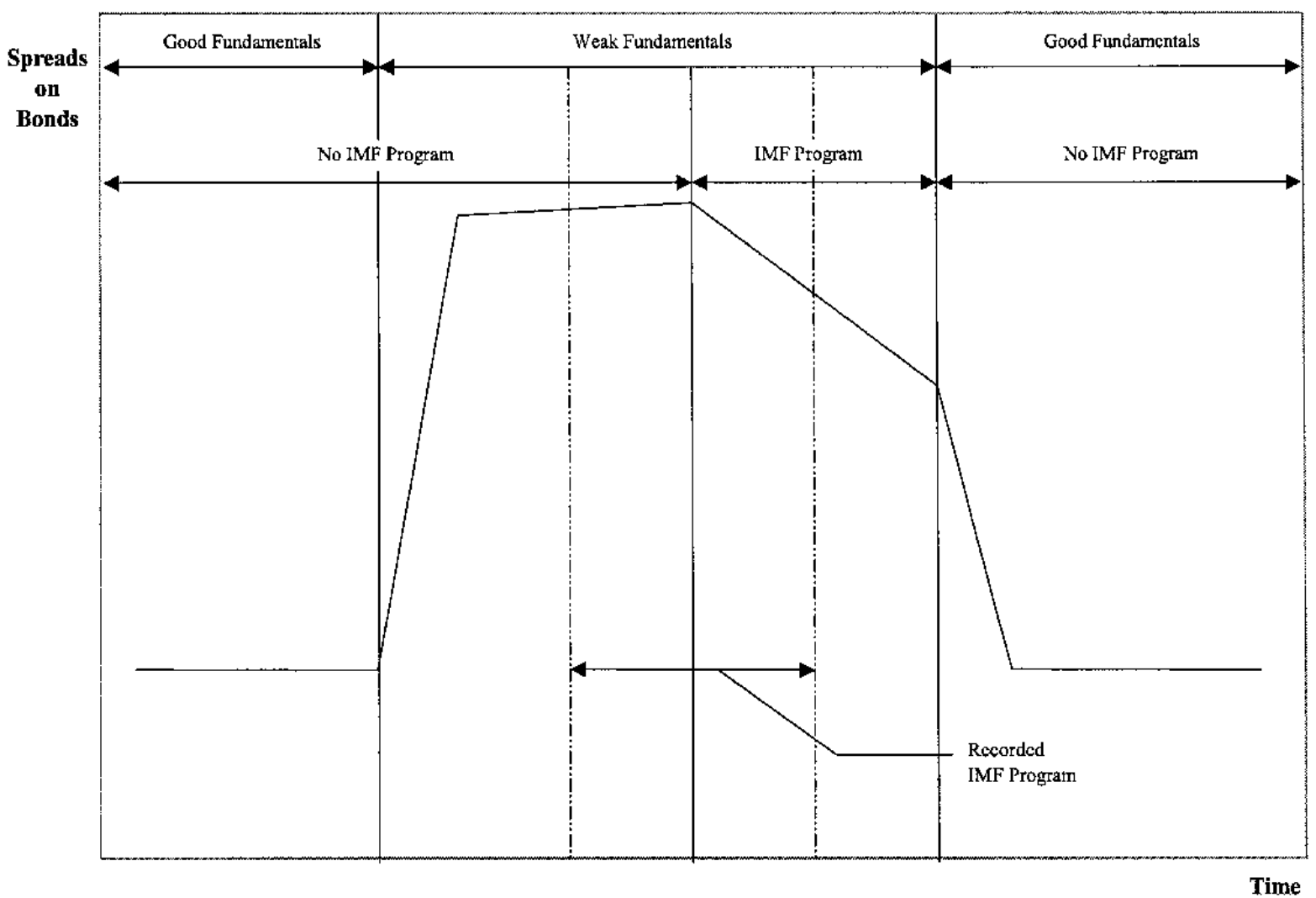




\section{DATA SOURCES AND CONSTRUCTION OF VARIABLES}

\section{Bond characteristics}

The bond dataset, obtained from Bondware, supplemented by the former Emerging Markets Division of the International Monetary Fund for the early 1990s, covers the period 1991 to 1999 and includes: (1) launch spreads over risk free rates (in basis points, where one basis point is onehundredth of a percentage point); (2) the amount of the issue (millions of US\$); (3) the maturity in years; (4) whether the borrower was a sovereign, other public sector entity, or private debtor; (5) currency of issue; (6) whether the bond had a fixed or floating rate; (7) borrower's industrial sector: manufacturing, financial services, utility or infrastructure, other services, or government (where government, in this case, refers to subsovereign entities and central banks, which could not be classified in the other four industrial sectors).

\section{Global variables}

United States industrial production growth rate: average of month-month growth rate over a quarter.

United States ten-year swap spread.

Emerging Market Bond Index: standard deviation of difference in log of daily spreads. 
Table 5. Country Characteristics

\begin{tabular}{|c|c|c|c|c|}
\hline Variable & (Billions) & Periodicity & Source & Series \\
\hline $\begin{array}{l}\text { Total external debt } \\
\text { (EDT) }\end{array}$ & US\$ & Annual & WEO & $\mathrm{D}$ \\
\hline $\begin{array}{l}\text { Gross national } \\
\text { product (GNP, } \\
\text { current prices) }\end{array}$ & US\$ & Annual & WEO & NGDPD \\
\hline $\begin{array}{l}\text { Gross domestic } \\
\text { product (GDPNC, } \\
\text { current prices) }\end{array}$ & National & Annual & WEO & NGDP \\
\hline $\begin{array}{l}\text { Gross domestic } \\
\text { product (GDP90, } \\
1990 \text { prices) }\end{array}$ & National & Annual & WEO & NGDP_R \\
\hline $\begin{array}{l}\text { Total debt service } \\
\text { (TDS) }\end{array}$ & US\$ & Annual & WEO & DS \\
\hline Exports (XGS) & US\$ & Annual & WEO & $\mathrm{BX}$ \\
\hline Exports (X) & US\$ & Monthly & IFS & $\mathrm{M \# c|70 \_ dzf}$ \\
\hline $\begin{array}{l}\text { Reserves } \\
\text { (RESIMF) }\end{array}$ & US\$ & Quarterly & IFS & 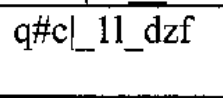 \\
\hline Imports (IMP) & US\$ & Quarterly & IFS & $\mathrm{qHc|} 71 \ldots \mathrm{dzf}$ \\
\hline $\begin{array}{l}\text { Domestic bank } \\
\text { credit } \\
(\mathrm{CLM} \text { PVT) })^{1}\end{array}$ & National & Quarterly & IFS & $\mathrm{qHc} \mid 32 \mathrm{~d} \quad \mathrm{zf}$ \\
\hline $\begin{array}{l}\text { Short-term bank } \\
\text { debt (BISSHT) }\end{array}$ & US\$ & semi-annual & BIS & \\
\hline $\begin{array}{l}\text { Total bank debt } \\
\text { (BISTOT) }^{3}\end{array}$ & US\$ & semi-annual & BIS & \\
\hline $\begin{array}{l}\text { Credit rating } \\
\text { (CRTG) }\end{array}$ & Scale & semi-annual & $\begin{array}{l}\text { Institutional } \\
\text { Investor }\end{array}$ & \\
\hline $\begin{array}{l}\text { Debt rescheduling } \\
\text { (DRES) }^{4}\end{array}$ & Indicator & Annual & WDT/GDF & \\
\hline
\end{tabular}


Table 5 (continued). Country Characteristics

Constructed Variables

\begin{tabular}{|l|l|}
\hline Debt/GNP & EDT/GNP \\
\hline Debt service/exports & TDS/XGS \\
\hline GDP/growth & $0.25^{*} \ln \left[\mathrm{GDP} 90 \_t / G D P 90 \_\{t-1\}\right]$ \\
\hline Standard deviation of export growth & $\begin{array}{l}\text { Standard deviation of monthly growth rates of } \\
\text { exports (over six months) }\end{array}$ \\
\hline Reserves/imports & RESIMF/IMP \\
\hline Reserves/GNP & RESIMF/GNP \\
\hline Reserves/short-term debt & RESIMF/BISSHT \\
\hline Short-term debt/total debt & BISSHT/BISTOT \\
\hline Domestic credit/GDP & CLM_PVT/(GDPNC/4) \\
\hline
\end{tabular}

Sources: International Monetary Fund's World Economic Outlook (WEO) and International Financial Statistics (IFS); $\mathrm{IMF}$ program data from the IMF's Executive Board Documents and Staff Estimates; World Bank's World Debt Tables (WDT) and Global Development Finance (GDF); Bank of International Settlements' The Maturity, Sectoral, and Nationality Distribution of International Bank Lending. Credit ratings were obtained from Institutional Investor's Country Credit Ratings. Missing data for some countries was completed using the US State Department's Annual Country reports on Economic Policy and Trade Practices (which are available on the internet from http:www.state.gov/www/issues/economic/trade_reports/). U.S. industrial production: Federal Reserve Swap rates and EMBI from Bloomberg.

${ }^{1}$ Credit to private sector.

${ }^{2}$ Cross-border bank claims in all currencies and local claims in nonlocal currencies of maturity up to and including one year.

${ }^{3}$ Total consolidated cross-border claims in all currencies and local claims in nonlocal currencies.

${ }^{4}$ Indicator variable, which is equal to one if a debt rescheduling took place in the previous year and zero otherwise. 


\section{BASE REgRESSION}

In this appendix we present the full details of the base regression, which corresponds to Column 1 of Table 3. As noted, in Tables 3 and 4 of the main text we present only the variables of direct interest to this paper. The signs and significance of the controls variables presented here remain very similar across the various variations in Tables 3 and 4 . The first two columns of the table in this appendix present the coefficient and z-statistic for the variables in the "selection equation," the probit; and the next two columns refer to the spreads equation.

While much of the table is self-explanatory, a few comments are in order. In earlier work (e.g., Eichengreen and Mody, 2001), we used the United States' 10-year treasury rate as one of the "global" variables. That variable gave ambiguous signs. In ongoing work, we find that U.S. industrial growth rate gives a consistent sign and also has an intuitive explanation in terms of U.S. higher growth improving credit quality for emerging market borrowers. Thus, a higher U.S. growth is associated with lower spreads and more frequent bond issuance, as if the demand for emerging market bonds shifts to the right when the United States grows more rapidly. Another new variable used in this analysis is the standard deviation of the daily log change of the EMBI index. A higher standard deviation implies greater market uncertainty with respect to pricing of bonds. We find that such uncertainty reduces bond issuance significantly and raises spreads (that the effect on spreads is not always significant at the 5 percent level). 
Table 6. Base Regression Results

\begin{tabular}{|c|c|c|c|c|}
\hline & \multicolumn{2}{|c|}{$\begin{array}{l}\text { Probability of Bond } \\
\text { Issuance } \\
\text { (Sclection Equation) }\end{array}$} & \multicolumn{2}{|c|}{$\begin{array}{c}\text { Log of Spread at the Time } \\
\text { of Issue }\end{array}$} \\
\hline & Coefficient & z-statistic & Coefficient & z-statistic \\
\hline \multicolumn{5}{|l|}{ Bond Characteristics } \\
\hline Log amount & & & -0.031 & $(-2.14)$ \\
\hline Maturity & & & 0.010 & $(4.98)$ \\
\hline Yen & & & -0.321 & $(-6.97)$ \\
\hline Deutsche Mark & & & -0.091 & $(-2.09)$ \\
\hline Euro & & & -0.058 & $(-1.24)$ \\
\hline Other currencies & & & -0.190 & $(-4.39)$ \\
\hline Fixed rate & & & 0.366 & $(11.04)$ \\
\hline \multicolumn{5}{|l|}{ Global Variables } \\
\hline U.S. growth rate & 52.908 & $(10.90)$ & -25.052 & $(-5.25)$ \\
\hline Log swap rate & -0.319 & $(-8.28)$ & 0.460 & $(11.61)$ \\
\hline EMBI volatility & -17.359 & $(-11.15)$ & 6.059 & $(4.27)$ \\
\hline \multicolumn{5}{|l|}{ Country Characteristics } \\
\hline Credit rating & 0.033 & $(29.79)$ & -0.044 & $(-26.70)$ \\
\hline Debt/GNP & -1.264 & $(-15.61)$ & 0.970 & $(10.77)$ \\
\hline Debt service/exports & 1.281 & $(24.87)$ & & \\
\hline Debt restructured dummy & 1.058 & $(15.15)$ & -0.450 & $(-9.72)$ \\
\hline GDP growth & 0.994 & $(0.93)$ & -9.372 & $(-6.58)$ \\
\hline Short-term debt/total debt & -0.674 & $(-8.91)$ & 0.841 & $(7.42)$ \\
\hline Export growth volatility & -2.118 & $(-5.71)$ & 0.666 & $(3.10)$ \\
\hline Reserves/imports & 0.073 & $(8.22)$ & -0.006 & $(-0.52)$ \\
\hline Bank credit stock/GDP & -0.000 & $(-0.51)$ & 0.000 & $(1.37)$ \\
\hline \multicolumn{5}{|l|}{ Sector } \\
\hline Public & 0.024 & $(0.61)$ & 0.033 & $(0.54)$ \\
\hline Finance & & & -0.127 & $(-1.96)$ \\
\hline Services & & & 0.506 & $(3.23)$ \\
\hline Utilities & & & -0.085 & $(-1.26)$ \\
\hline Private & 0.639 & $(25.19)$ & 0.083 & $(1.75)$ \\
\hline Finance & & & -0.199 & $(-6.18)$ \\
\hline Services & & & 0.129 & $(2.32)$ \\
\hline Utilities & & & -0.131 & $(-3.20)$ \\
\hline Latin America Dummy & & & 0.021 & $(0.63)$ \\
\hline IMF program dummy & 0.337 & $(\mathbf{1 0 . 6 0 )}$ & -0.089 & $(-3.06)$ \\
\hline Constant & -0.249 & $(-1.41)$ & 5.238 & $(28.02)$ \\
\hline Lambda & & & -0.520 & $(-11.55)$ \\
\hline Number of observations & & & 7882 & \\
\hline Number of bonds & & & 2990 & \\
\hline Log of likelihood & & & $-5,991.4637$ & \\
\hline
\end{tabular}

Note: z-statistics, based on robust standard errors, are presented in the parentheses. 


\section{REFERENCES}

Bagci, P., and W. Perraudin, 1997, "The Impact of IMF Programs," The Institute for Financial Research, Working Paper IFR35 (London: Birkbeck College, University of London).

Barro, R. J., and J. W. Lee, 2001, "IMF Programs: Who Is Chosen and What Are the Effects?" paper presented at the Second Annual IMF Research Conference, Washington, November 7-8, 2001. Also available on the internet at: www.imf.org/external/pubs/ft/staffp/2001/00-00/arc.htm.

Bird, G., and D. Rowlands, 1997, "The Catalytic Effect of Lending by the International Financial Institutions," World Economy, Vol. 20, No. 7 (November), pp. 81-97.

- 2001a, "Catalysis or Direct Borrowing: The Role of the IMF in Mobilising Private Capital," World Economy, Vol. 24, No.1 (January), pp. 81-97.

_ 2001b, "IMF Lending: How is it Affected by Economic, Political, and Institutional Factors?" Policy Reform, Vol. 4, pp. 243-270.

$\longrightarrow$, 2002, "Do IMF Programmes Have a Catalytic Effect on Other International Capital Flows?" Oxford Development Studies, Vol. 30, No. 3, pp. 229-49.

Bordo, M. and H. Rockoff, 1996, "The Gold Standard as a Good Housekeeping Seal of Approval," Journal of Economic History, Vol. 56, No. 2 (June), pp. 389-428.

Bordo, M., M. Edelstein, and H. Rockoff, 1999, "Was Adherence to the Gold Standard a 'Good Housekeeping Seal of Approval' During the Interwar Period?' NBER Working Paper No. 7186 (Cambridge, Massachusetts: National Bureau of Economic Research).

Boughton, J.M., 2001, "The Silent Revolution: The International Monetary Fund: 1979_ 1989," (Washington: International Monetary Fund).

Catão, Luis A., and Bennett W. Sutton, "Sovereign Defaults: The Role of Volatility," IMF Working Paper No. 02/149 (Washington: International Monetary Fund).

Conway, P., 1994, “IMF lending programs: Participation and Impact," Journal of Development Economics, Vol. 45, No 2 (December), pp. 365-91.

_, 2000, "IMF Programs and External Balance: the Crisis-Participation Dynamic" (University of North Carolina, mimeo).

__ 2001, "Evaluating Fund Programs" (unpublished; Chapel Hill: University of North Carolina). 
Corsetti, Giancarlo, Bernardo Giumarães, and Nouriel Roubini, 2003, "The Tradeoff Between an International Lender of Last Resort to Deal with Liquidity Crisis and Moral Hazard Distortions: A Model of the IMF's Catalytic Finance Approach." http://www.stern.nyu.edu/globalmacro/

Dell'Ariccia, Giovanni, Isabel Schnabel, and Jeromin Zettelmeyer, 2002, Moral Hazard and International Crisis Lending: A Test, IMF Working Paper 02/181 (Washington: International Monetary Fund).

Dhonte, P., 1997, "Conditionality as an Instrument of Borrower Credibility." IMF Paper on Policy Analysis and Assessment, No. 2.

Dicks-Mireaux, L., M. Mecagni, and S. Schadler, 2000, "Evaluating the Effect of IMF Lending to Low-Income Countries," Journal of Development Economics, Vol. 61, pp. 495-526.

Eaton, J., and M. Gersovitz, 1981, "Debt with Potential Repudiation: Theoretical and Empirical Analysis,” Review of Economic Studies, Vol. 48, pp. 289-309.

Edwards, S., 1989, "The International Monetary Fund and the Developing Countries: A Critical Evaluation," NBER Working Paper 2909 (Cambridge, Massachusetts: National Bureau of Economic Research).

Edwards, M. S., 2000, "Reevaluating the Catalytic Effect of IMF Programs," [resented at the Annual Meeting of the American Political Science Association. Available via the Internet www.rci.rutgers. edu $\sim$ mse.

Eichengreen, B. and A. Mody, 2001, "Bail-Ins, Bail-Outs, and Borrowing Costs," IMF Staff Papers, Vol. 47, pp.155-87.

Fisher, S., 1997, “Applied Economics in Action: IMF Programs," The American Economic Review, Vol. 87, pp. 23-27.

Garuda, G., 2000, "The Distributional Effects of IMF Programs: A Cross-Country Analysis". World Development, Vol. 28, No. 6, pp. 1031-51.

Goldstein, M., and P. Montiel, 1986, "Evaluating Fund Stabilization Programs with Multicountry Data: Some Methodological Pitfalls," IMF Staff Papers, Vol. 33, pp. 304-44.

Hajivassiliou, V., 1987, “The External Debt Repayment Problems of LDC's: An Econometric Model Based on Panel Data," Journal of Econometrics, Vol. 36, pp. 205-30. 
Hale, D., 1998, "The IMF, Now More than Ever: The Case for Financial Peacekeeping," Foreign Affairs, Vol. 77, No. 6, pp. 7-13.

Heckman, James, 1979, "Sample Selection Bias as a Specification Error," Econometrica, Vol. 47, pp.153-161.

Hutchison, M., 2001, "A Cure Worse Than The Disease? Currency Crises and the Output Costs of IMF-Supported Stabilization Programs," NBER Working Paper No. 8305 (Cambridge, Massachusetts: National Bureau of Economic Research).

International Monetary Fund, 2001a, "Financial Organization and Operations of the IMF," Treasurer's Department (Washington: International Monetary Fund).

—, 2001b, "Selected Decisions and Selected Documents of the International Monetary Fund" (Washington: International Monetary Fund).

,- 2002 , "Evaluation of the Prolonged Use of Fund Resources," Volumes I and II, (Washington: International Monetary Fund).

Ivanova, A., W. Mayer, A. Mourmouras, and G. Anayiotos, 2001, "What Determines the Implementation of IMF -Supported Programs? IMF Working Paper No. 03/8 (Washington: International Monetary Fund).

Kaminsky, G.L. and S.L. Schmukler, 1999, "What Triggers Market Jitters: A Chronicle of the Asian Crisis," Journal of International Money and Finance, Vol. 18, pp. 537-60.

Khan, M., 1990, "The Macroeconomic Effects of Fund-Supported Adjustment Programs," IMF Staff Papers, Vol. 37, pp. 195-231.

Killick, T., M. Malik, and M.Manual, 1992, What Can We Know About the Effects of IMF Programmes? World Economy (U.K.), Vol. 15, pp. 575-97.

Köhler, Horst, 2001, "Promoting Stability and Prosperity in a Globalized World". Remarks by IMF Managing Director, Council of the Americas, Washington, DC, May 7, 2001. http://www.imf.org/external/np/speeches/2001/050701.htm

Krueger, A., 2000, "Conflicting Demands on the International Monetary Fund," American Economic Association Papers and Proceedings, Vol. 90, No. 2, pp. 38-42.

Lane, T., and S. Phillips, 2000, "Does IMF Financing Result in Moral Hazard," IMF Working Paper No. 00/168 (Washington: International Monetary Fund).

Leung, S. F., and S. Yu, 1996, "On the Choice Between Sample Selection and Two-Part Models," Journal of Econometrics, Vol. 72, pp. 197-229. 
Marchesi, S., 2001, "Adoption of an IMF Programme and Debt Rescheduling. An Empirical Analysis," Centro Studi Luca D' Agliano, Development Studies Working Papers, No. 152.

—, and J. P. Thomas, 1999, "IMF Conditionality as a Screening Device," The Economic Journal, Vol. 109, pp. 111-125.

Morris, Stephen, and Hyun Shong Shin, 2003, "Catalytic Finance: When Does it Work?" Cowles Foundation Discussion Paper No. 1400, February 2003.

Mussa, M., and M. Savastano, 1999, "The IMF Approach to Economic Stabilization," IMF Working Paper No. 99/104 (Washington: International Monetary Fund).

Obstfeld, M., and A. M. Taylor, 2002, "Sovereign Risk, Credibility and Gold Standard: 1870-1913 Versus 1925-31," NBER Working Paper 9345 (Cambridge, Massachusetts: National Bureau of Economic Research).

Ozler, S., 1993, "Have Commercial Banks Ignored History?" The American Economic Review, Vol. 83, pp. 608-20.

Pattillo, Catherine, Hélène Poirson, and Luca Ricci, 2002, "External Debt and Growth," IMF Working Paper No. 02/69 (Washington: International Monetary Fund).

Powell, A, 2002, 'Countries in Payments' Difficulties: What Can the IMF Do?' International Monetary Fund Seminar Series (International); No. 2002-66:1-[36], May 2. htp:/www-intapps.imforg/Res/Seminars/SemPapers_all.asp?scope $=$ res

Prezeworski, Adam and James Raymond Vreeland, 2000, "The Effect of IMF Programs on Economic Growth," Journal of Development Economics, Vol. 62, pp.385-421.

Schadler, S., and others, 1995a, IMF Conditionality: Experience Under Stand-By and Extended Arrangements, Part I: Key Issues and Findings, IMF Occasional Paper No. 128 (Washington: International Monetary Fund).

- 1995b, IMF Conditionality: Experience Under Stand-By and Extended Arrangements, Part II: Background Papers, IMF Occasional Paper No. 129 (Washington: International Monetary Fund).

Stone, R., 2002, "Lending Credibility" (Princeton, New Jersey: Princeton University Press).

Tirole, J. 2002, Financial Crises, Liquidity, and the International Monetary System (Princeton, New Jersey: Princeton University Press). 